\title{
External morphology of the immature stages of Neotropical heliconians: X. Heliconius sara apseudes (Lepidoptera, Nymphalidae, Heliconiinae)
}

\author{
Kim R. Barão, Denis S. Silva \& Gilson R. P. Moreira
}

PPG Biologia Animal, Departamento de Zoologia, Instituto de Biociências, Universidade Federal do Rio Grande do Sul, Av. Bento Gonçalves, 9500 , Bloco IV، Prédio 43435, 91501-970 Porto Alegre, RS, Brazil. (kbarao@yahoo.com.br; denissantossilva@yahoo.com.br; gilson.moreira@ufrgs.br)

\begin{abstract}
The biology and morphology of the immature stages of Heliconius sara apseudes (Hübner, [1813]) are still little known. External features of the egg, larvae and pupa of $H$. sara apseudes are described and illustrated, based upon light and scanning electron microscopy. Eggs with smooth carina, first instar larva with scaly setae, and body of second to fifth instars covered with scattered pinnacles distinguish $H$. sara apseudes from other heliconiine species.
\end{abstract}

KEYWORDS. Passion vine butterflies, egg, larva, pupa, tegumentary ultrastructure.

RESUMO. Morfologia externa dos estágios imaturos de heliconíneos Neotropicais: X. Heliconius sara apseudes (Lepidoptera, Nymphalidae, Heliconiinae). A biologia e morfologia de estágios imaturos de Heliconius sara apseudes (Hübner, [1813]) ainda são pouco conhecidos. Características da morfologia externa dos ovos, larvas e pupa de $H$. sara apseudes são descritas e ilustradas, utilizando-se microscopias óptica e eletrônica de varredura. Ovos com carenas lisas, larvas de primeiro instar com cerdas contendo projeções escamiformes e larvas do segundo ao quinto instares com corpo apresentando pináculas dispersas são características distintivas de $H$. sara apseudes em relação às demais espécies de heliconíneos.

PALAVRAS-CHAVE. borboletas do maracujá, ovo, larva, pupa, ultraestrutura tegumentar.

Within the genera Heliconius Kluk, 1780, Eueides Hübner, 1816 and Neruda Turner, 1976, Heliconius sara (Fabricius, 1793) is one of the few species that has bluishblack fore- and hind wings with either yellow or white stripes. This species is included within a clade commonly called sara/sapho, which is comprised of 12 species (Beltrán et al., 2007; KozAK et al., 2015). Most species within this clade show the same wing color patterning (Holzinger \& Holzinger, 1994), except $H$. demeter Staudinger, 1897. They have gregarious larval habits (exceptions are $H$. demeter, H. charitonia (Linnaeus, 1767), and H. peruvianus C. Felder \& R. Felder, 1859; BELTRÁN et al., 2007) and all show pupal-mating behavior (Beltrán et al., 2007).

With a broad distribution in Central and South America, most subspecies of $H$. sara occur in the Amazonian region (Rosser et al., 2012). Heliconius sara apseudes (Hübner, [1813]) is the only subspecies found throughout the South American Atlantic Forest (EMSLEY, 1963; Holzinger \& Holzinger, 1994; Rosser et al., 2012). Recently, CARDoso (2005) and IsERHARD et al. (2010) recorded new localities of $H$. sara apseudes, extending its northern and southern distributions to states of Bahia and Rio Grande do Sul, respectively.

Heliconius sara lays egg clusters at the branch apex of passion-vines (Passifloraceae) and larvae are semigregarious. Five species of host plants are recorded for $H$. sara apseudes in southeastern Brazil (BeCCALONI et al., 2008): Passiflora edulis Sims, $P$. pentagona Masters, $P$. rhamnifolia Masters [ $=$ P. sidaefolia (M. Roemer)], and $P$. ovalis Vell. ex M. Roem. Additional field observations made by us indicate that this subspecies also uses $P$. truncata Regel and P. haematostigma Masters in Santa Catarina and Paraná states, respectively.

Even though resources exist to enable species identification at early stages and to elucidate taxonomic and phylogenetic relationships (e.g. PENZ, 1999), the natural history and external tegumentary ultrastructure of immature stages of species of the sara/sapho clade are still poorly documented. Descriptions of immature stages of $H$. sara are available only at the gross-morphology level for the subspecies occurring in Trinidad and Tobago (BEEBE et al., 1960; Fleming, 1960), and few species diagnostic characteristics have been supplied by BROwN (1981).

As part of a series of articles focusing on the external morphology of the immature stages of Neotropical heliconiines (ANTUNES et al., 2002; KAMINSKI et al., 2002, 2008; TaVares et al., 2002; Paim et al., 2004; Silva et al., 2006, 2008; BarÃo \& Moreira, 2010; Vargas et al., 2014), here we describe and illustrate in detail the early stages of $H$. sara apseudes based on light and scanning electron microscopy.

\section{MATERIAL AND METHODS}

Eggs and larvae were collected from leaves of $P$. haematostigma in Quatro Barras municipality, Paraná, Brazil. Eggs were placed on moist filter paper in Petri dishes for incubation. After hatching, larvae were grown on branches of $P$. haematostigma, kept in plastic bottles 
equipped with a wire support. The bottles were filled with tap water, covered with a fine mesh, and kept under laboratory conditions $\left(25 \pm 1^{\circ} \mathrm{C}, 14 \mathrm{~h}\right.$ light/day). Head capsules were collected after each ecdysis, fixed in Dietrich's fluid, and preserved in 70\% ethanol. Additional eggs, larvae and pupae were also similarly fixed and preserved. The examined material was deposited in the collection of the Laboratório de Morfologia e Comportamento de Insetos (LMCI), of the Departamento de Zoologia, Universidade Federal do Rio Grande do Sul (UFRGS), Porto Alegre, Rio Grande do Sul, Brazil, under accession numbers 132 and 136.

Aspects of general morphology of immature stages were analyzed from material preserved in ethanol $70 \%$. Head capsules were rehydrated, cleared in a $10 \%$ potassium hydroxide solution $(\mathrm{KOH})$, and slide-mounted in glycerin jelly. Drawings were made from preserved specimens, using a reticulated ocular attached to a Leica ${ }^{\circledR}$ M125. The tegumentary ultrastructure was studied at the Centro de Microscopia Eletrônica (CME) of UFRGS. Specimens were dehydrated in a Bal-Tec ${ }^{\circledR}$ CPD 030 critical-point dryer, mounted with double-sided tape on metal stubs, coated with gold in a Bal-Tec ${ }^{\circledR}$ SCD 050 sputter coater, and analyzed on a JEOL ${ }^{\circledR}$ JSM-6060 scanning electron microscope.

To distinguish larval instars, the greatest width of the head capsule in frontal view was measured with a micrometer scale mounted in the ocular of the stereomicroscope. By using the least-squares method, the resulting data were adjusted to the power function $y$ $=\mathrm{ae}^{\wedge} \mathrm{bx}$ (SNEDECOR \& COCHRAN, 1980).

The nomenclature of DELL'ERBA et al. (2005) is used for eggs, PETERSOn (1962) for larval body regions, STEHr
(1987) for primary chaetotaxy and crochet of prolegs, Kitching (1984) for the setae of the paraproct and of the anal prolegs, BEEBE et al. (1960) for the scoli, and MosHER (1916) for the pupa.

\section{RESULTS AND DISCUSSION}

Egg (Figs 1-5, 32). Barrel-shaped, base flat, apex narrower than base (Fig. 1). Dimensions (mean \pm standard error; $\mathrm{n}=10$ ): diameter $=0.779 \pm 0.010 \mathrm{~mm}$; height $=1.004$ $\pm 0.017 \mathrm{~mm}$. These heights are slightly larger than those found by BEEBE et al. (1960) and BRown (1981). Yellow (Fig. 32) throughout embryonic development, differing from BEEBE et al. (1960), who observed varying shades of pale yellow and orangish-yellow.

Chorion ornamented with vertical (Vr) and horizontal (Hr) smooth carinae (Fig. 1), differing from $H$. erato phyllis (Fabricius, 1775), H. ethilla narcaea Godart, 1819 , and $H$. besckei Ménétriés, 1857, which have rugose carinae (DELL'ERBA et al., 2005). Vertical carinae twice as thick as horizontal ones (Fig. 5). Carina number varying from 13 to $14 \mathrm{Vr}$ and from 8 to $10 \mathrm{Hr}$. BEEBE et al. (1960) and BROWN (1981) found slightly lower values for $\mathrm{Hr}$ (6-8 and 7, respectively). Intersections of vertical and horizontal carinae delimit cells; surface of cells rugose close to carinae and smooth medially (Fig. 3). Lower cells (Lc; Fig. 5) tetragonal; upper cells (Uc; Fig. 3) varying from tetragonal to hexagonal. Apical Hr border the micropylar region (Fig. 2), but do not project over it as found in $H$. erato phyllis (KAMINSKI et al., 2002). Micropylar region ornamented with polygonal, rugose cells peripherally, forming the annulus, and smooth cells centrally, forming the rosette, in the center of which are the micropyles (Mp;
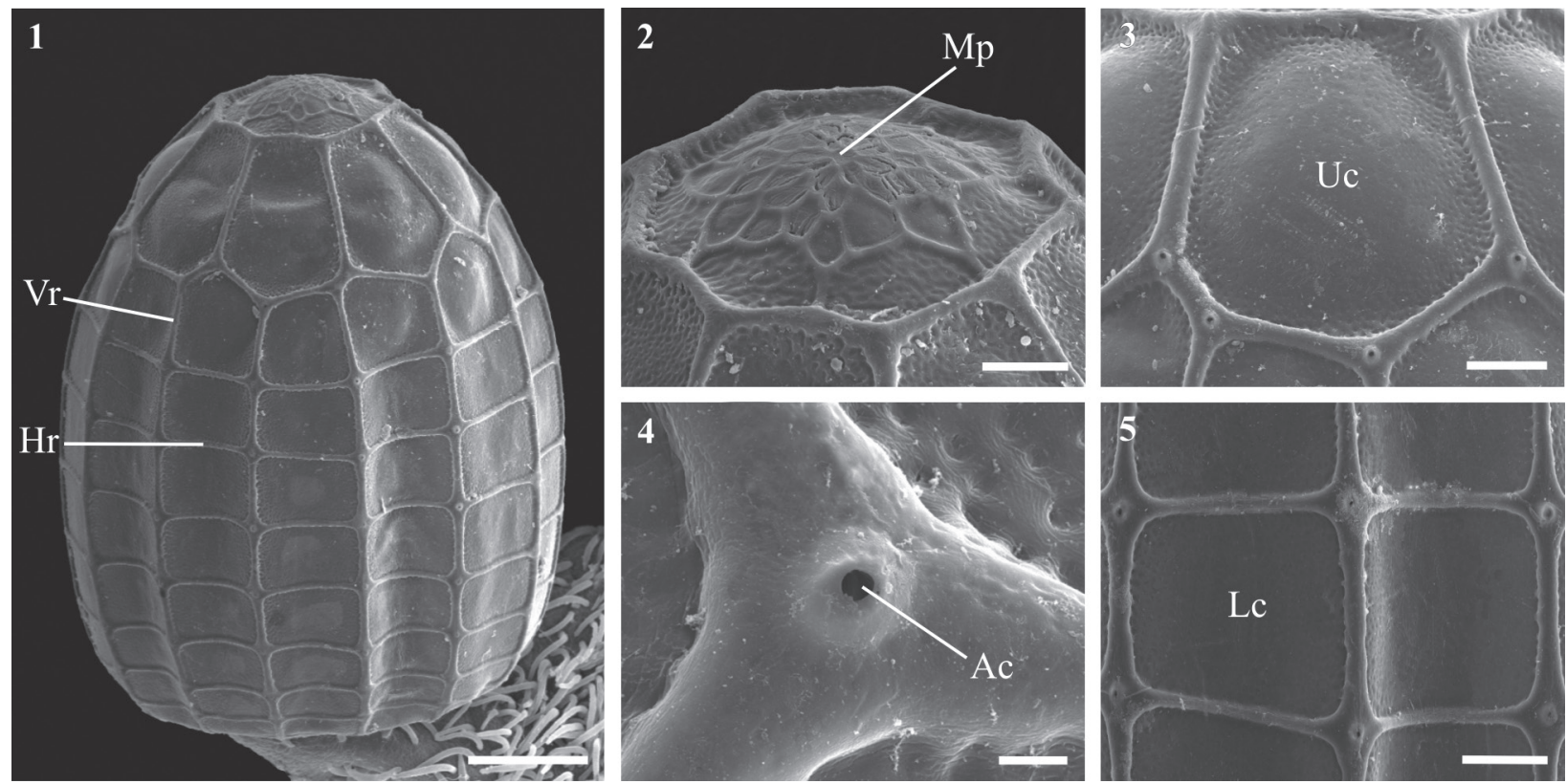

Figs 1-5. Scanning electron micrographs of the egg of Heliconius sara apseudes (Hübner, [1813]). 1, lateral view; 2, micropylar region; 3, upper cells; 4, aeropyle; 5, lower cells (Ac, aeropyle; Hr, horizontal carina; Lc, lower cell; Mp, micropyles; Uc, upper cell; Vr, vertical carina). Bars = $200,100,100,10$, and $100 \mathrm{~mm}$, respectively. 
Fig. 2; Downey \& Allyn, 1981). Circular aeropyles with slightly elevated peritreme at carina intersections (Ac; Fig. 4), similar to all Heliconius species cited above.

Eggs of $H$. sara apseudes can be distinguished from those of Agraulis Boisduval \& Le Conte, [1835], Dione Hübner, [1819], Dryadula Michener, 1942, Dryas Hübner, [1807], Eueides and Philaethria Billberg, 1820 studied by DelL'Erba et al. (2005) by having the surface of cells rugose close to the carinae and smooth medially. From Heliconius species also studied by these authors, $H$. sara apseudes is distinguishable by its smooth carinae.

First-instar larva (Figs 6-9, 11-20, 34). Head dark-brown with blackish stripe basally, stemmatal region blackish. Thorax and abdomen yellow; prothoracic dorsal shield, anal shield, pinnacles, legs, and lateral plates of prolegs brown; setae black, unpigmented apically (Fig. 34). Coloration of first-instar larva of Heliconius sara apseudes differs markedly from other species of Heliconius: lightcolored head, plates, and pinnacles have been recorded in $H$. besckei, H. erato phyllis and H. ethilla narcaea.

Head and mouthparts (Figs 6-7, 13) of first-instar larva following morphological pattern of Lepidoptera (STEHR, 1987). Frons and clypeus fused, frontoclypeal suture inconspicuous (Fig. 6); anteclypeus as a straight transverse stripe between frontoclypeus and labrum; labrum ample, bilobed, partially covering mandibles in frontal view; antennal pocket smooth, lateral to mouthparts; antennae trisegmented (Fig. 12); six stemmata dorsal to antennal pocket, stemmata 1-5 in semicircle, stemma 6 slightly posterior to imaginary line from stemmata 1 to 5 , stemmata 1 to 4 equidistant from each other (Figs 7, 11).

Setae of chalaza type, clavate apically; setae covered with scale-like projections (Figs 15, 16). On head (Figs 6, 7), pairs of setae, microsetae, and pores are clustered in ten groups. Adfrontal (AF) group: setae AF1 and AF2 close to superior angle of frontoclypeus; $\mathrm{AFa}$ pore between $\mathrm{AF}$ setae, closer to AF2. Anterior (A) group: A1 anterior to stemma 1; A2 and A3 dorsal to stemmata; Aa pore close to stemmata 2 and 3. Clypeal (C) group: bisetose; setae near ventral margin of frontoclypeus; $\mathrm{C} 2$ closer to adfrontal suture. Cephalo-dorsal (CD) group: CD1, CD2 and CD3 microsetae posterior to $\mathrm{P} 2$; $\mathrm{CDa}$ pore between $\mathrm{CD} 1$ and CD2. Frontal (F) group: F1 slightly displaced from midline toward ventral half of frontoclypeus; Fa pore dorsally to F1. Lateral (L) group: L1 about midway between P2 and S2; La pore posterior to L1. Microgenal (MG) group: MG1 a microseta; $\mathrm{MGa}$ anterodorsal to MG1. Posterodorsal (P) group: $\mathrm{P} 2$ dorsal to $\mathrm{P} 1$, both same size; Pa pore ventral to $\mathrm{P} 1$ and $\mathrm{Pb}$ pore between $\mathrm{P} 1$ and $\mathrm{P} 2$. Stemmatal (S) group: $\mathrm{S} 1$ in center of stemmatal area; S2 and S3 posterior to stemmata; Sa pore posterior to stemmata; $\mathrm{Sb}$ pore anterior to stemma 4. Substemmatal (SS) group: SS2 level with stemma 5; SS1 and SS3 ventral to stemmata; SSa pore ventral to stemma 6 ; SSb pore ventral to stemma 5 .

Thorax and abdomen bear ten groups of setae (Figs 8, 9): prothoracic shield (XD), dorsal (D), subdorsal (SD), lateral (L), subventral (SV), ventral (V), paraproctal (PP), subparaproctal (SP), tarsal (Ts) and proleg of tenth segment (PL). Pores and microsetae occur scattered over tegument (Kitching, 1984), but are omitted here. On prothorax, prothoracic shield setae D1, D2, and XD2 (Fig. 8), D1 and D2 dorsally to XD2. SD setae on same pinnacle, SD1 anterior to and longer than SD2. L1 and L2 of same size, both on same pinnacle, anterior to spiracle; L1 at least half size of SD2, contrary to description by BEEBE et al. (1960) for another subspecies of H. sara, where L1 is considerably larger than SD2. SV on same pinnacle; SV1 larger than and ventral to SV2. On mesothorax (T2), D1 and D2 setae on separate pinnacles; D1 larger than and dorsal to D2. SD1 and SD2 on same pinnacle; SD1 larger than and anterior to SD2. Groups L and S each with one seta; L1 as long as SD1; SV1 shorter than SD2. Legs with tibial and tarsal setae Ts1, Ts2, Ts3, and Ts4 (sensu MiLLER, 1991); Ts4 longer than remaining tarsal setae, resembling tarsal claw (Ga, Fig. 14). Metathoracic (T3) setae similar in composition and arrangement to setae of $\mathrm{T} 2$.

Dorsal, subdorsal and lateral setae similar from first to eighth abdominal segments. D1 dorsal and anterior to D2. SD1 ventral to D2 and aligned with D1. Lateral group with two setae, each on semicircular pinnacle; L1 posterodorsal to L2. SV1 on AB1-9 and SV2 on AB2-6; on AB2, SV1 and SV2 share same pinnacle; on AB3-6, SV1 and SV2 on proleg shield. Small and slender V1 on $A B 2$. On AB9, pinnacles of D1 fused, visible in dorsal view; D2 and SD1 sharing same pinnacle, D2 dorsal to $\mathrm{SD} 1$; L1 as long as SD1. On AB10, dorsal and subdorsal setae on anal shield; D1 longer than and dorsal to D2, SD1 and SD2; paraproctal seta, PP1 (sensu STEHR, 1987), and subparaproctal seta, SP1 (sensu KiTcHING, 1984), are shorter and sharp, in relation to remaining setae on AB10; proleg with five setae, PL1 to PL4 visible in lateral view, PL5 visible only in ventral view, PL1 and PL2 longer than remaining PL setae.

Integument mostly smooth; ventral area, legs, prolegs, and paraproct provided with conical microtrichia (Fig. 17); those on paraproct elongate (Fig. 18). Spiracle round, peritreme elevated, present on prothorax and from $\mathrm{AB} 1$ to $\mathrm{AB} 8$ (Fig. 19). On base of prolegs, uniordinal and uniserial crochets arranged in circles (Fig. 20).

The gross morphology and chaetotaxy of the first instar of $H$. sara apseudes fit the general pattern described for Heliconiini (ANTUNES et al., 2002; KAMINSKI et al., 2002, 2008; TAVARES et al., 2002; PAIM et al., 2004; SiLVA et al., 2006, 2008; BARÃo \& Moreira, 2010; VARGAS et al., 2014). Several characteristics make it feasible to identify the first-instar larva of $H$. sara apseudes. First, the smooth antennal pocket is similar to the antennal pocket of $H$. erato phyllis (KAMINSKI et al., 2002), but differs from the rugose antennal pocket found in other species (TAVARES et al., 2002; PAim et al., 2004; SiLva et al., 2006, 2008; KAMINSKI et al., 2008). Second, the scale-like projections along the setae of $H$. sara apseudes are unique among the heliconiine species studied (e.g., KAMINSKI et al., 2002, 2008; SiLVA et al., 2006, 2008; BARÃo \& MoreIra, 2010; 

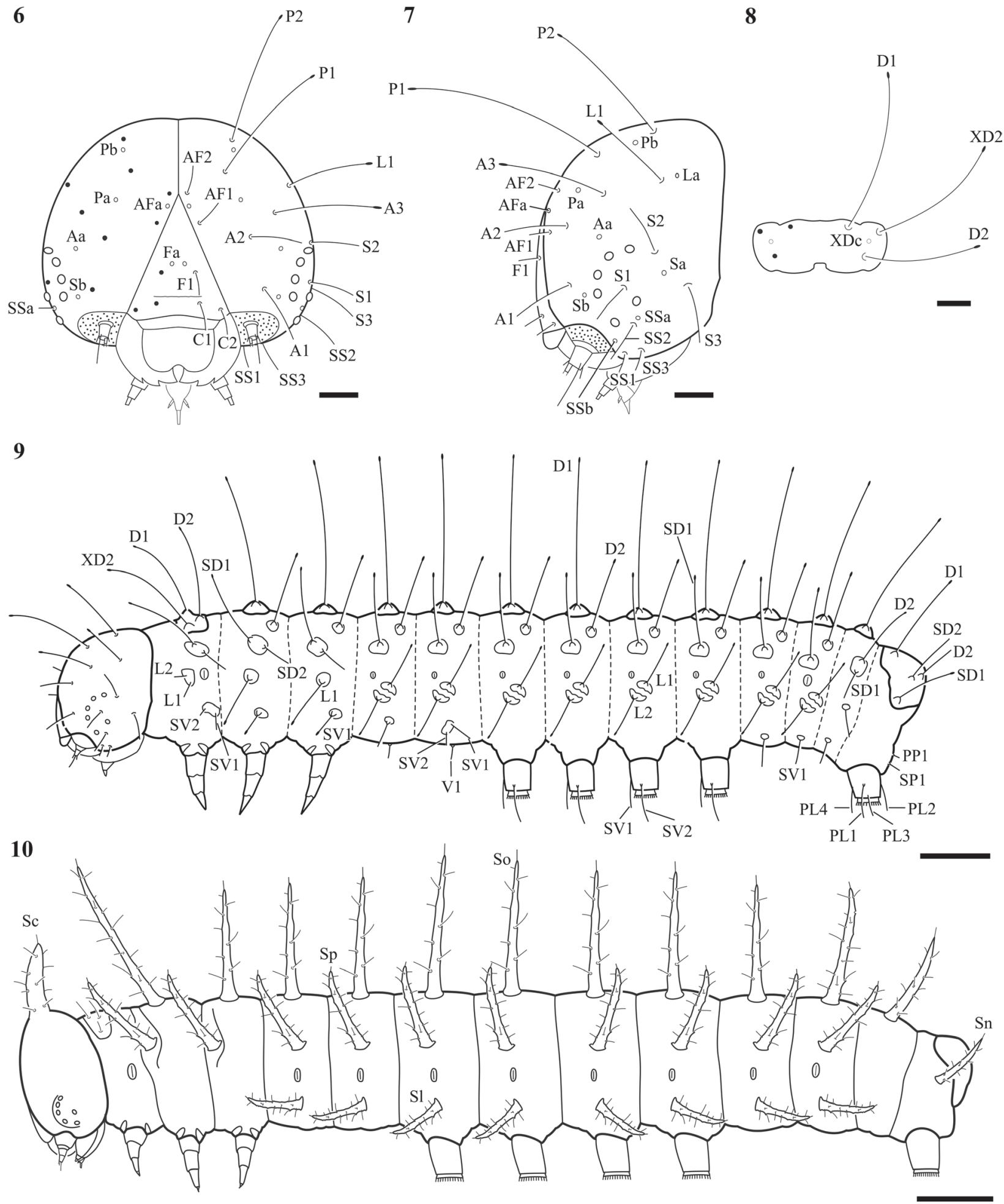

Figs 6-10. Head capsule, prothoracic plate and first and fifth instar larvae of Heliconius sara apseudes (Hübner, [1813]). 6, frontal view of first instar head capsule; 7, lateral view of first instar head capsule; 8, dorsal view of first instar prothoracic plate; 9, lateral view of first instar; 10, lateral view of fifth instar (A, anterior seta; Aa, anterior pore; AF, adfrontal seta; AFa, adfrontal pore; C, clypeal seta; D, dorsal seta; F, frontal seta; Fa, frontal pore; L, lateral seta; $\mathrm{P}$, posterodorsal seta; $\mathrm{Pa}$ and $\mathrm{Pb}$, posterodorsal pores; $\mathrm{PL}$, seta of proleg on cylindrical section of tenth abdominal segment; PP, paraproctal seta; S, stemmatal seta; Sa and Sb, stemmatal pores; Sc, cephalic scolus; SD, subdorsal seta; S1, subspiracular scolus; Sn, anal scolus; So, dorsal scolus; SP, subparaproctal seta; Sp, supraspiracular scolus; SS, substemmatal seta; SSa and SSb, substemmatal pores; SV, subventral seta; $\mathrm{V}$, ventral seta; XD, prothoracic seta; XDc, prothoracic pore). Bars =100, 100, 100, 250, and 2500 mm, respectively. 
VARGAS et al., 2014). Last, although lepidopteran AB9 chaetotaxy is very diverse (e.g., NAKANISHI, 1988; PALUCH et al., 1999, 2001; Murray, 2001; CASAGRANDE, 2002; SAKAMAKI \& HAYAKAWA, 2004; BaLlMER \& Wright, 2008), the clustering of D2 and SD1 setae on the same pinnacle is not reported for any other species of Heliconiini (ex: Fleming, 1960; ANTUNES et al., 2002; TAVARES et al., 2002; KAMINSKi et al., 2002, 2008; PAIM et al., 2004; SiLVA et al., 2006, 2008; Barão \& MoreIra, 2010; VARGaS et al., 2014).

Remaining instars (Figs 10, 21-31, 35). From the second instar on, both the chaetotaxy and coloration change (Fig. 35): secondary setae, scoli and verrucae arise, and the head becomes black; the general thoracic and abdominal color is grayish-yellow; and the prothoracic and anal shields, legs, prolegs, scoli, verrucae, and spiracles turn black.

Head with pair of short, stout cephalic scoli (Sc), measuring approximately half height of head; apex of cephalic scoli rounded, with more than one apical seta (Fig. 24). Mouthparts and stemmata (Fig. 21) as in first instar.

Thoracic and abdominal scoli with one apical seta (Figs 23, 25). Prothorax lacking scoli (T1; Figs 10, 35); prothoracic shield bearing setae D1, D2, and XD2 and several secondary setae (Fig. 22); primary setae at same
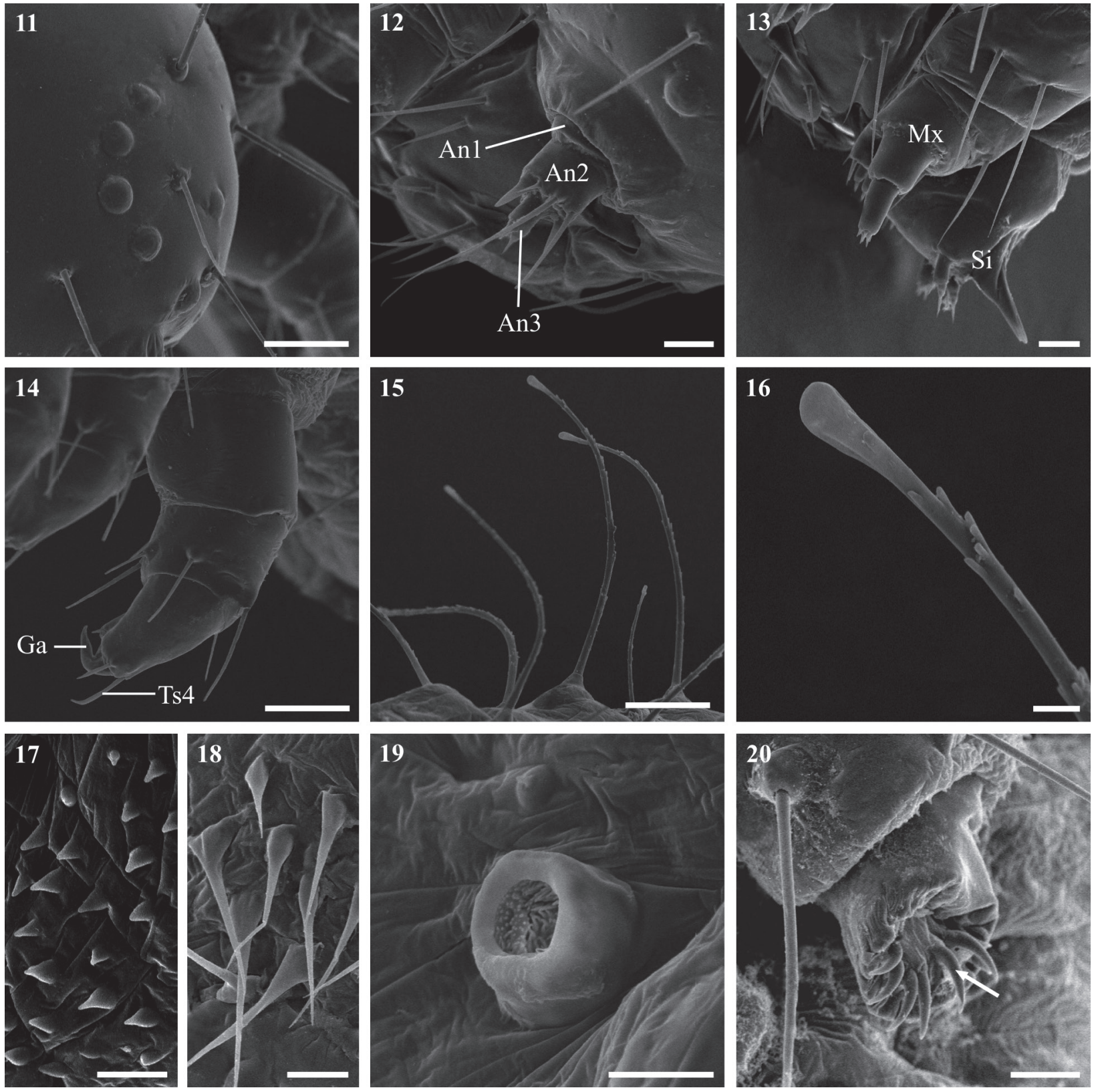

Figs 11-20. Scanning electron micrographs of the first instar larva of Heliconius sara apseudes (Hübner, [1813]). 11, stemmatal region, frontal view; 12, antenna, lateral view; 13, maxilla and spinneret, lateral view; 14, metathoracic leg, antero-lateral view; 15, chalazae, lateral view; 16, apex of dorsal seta; 17, microtrichia of ventral region of body; 18, microtrichia of anal plate; 19, spiracle of second abdominal segment; 20, base of proleg with exposed crochets (arrow) (An, antennomere; Ga, tarsal claw; Mx, maxilla; Si, spinneret; Ts, tarsal seta). Bars = 50, 20, 20, 50, 100, $10,10,10,10$ and $20 \mathrm{~mm}$, respectively. 
position as in first instar. Pair of dorsal (So) and supraspiracular (Sp) scoli on meso- (T2) and metathorax (T3); So on $\mathrm{T} 2$ projected anteriorly, $1.5 \mathrm{x}$ longer than So on remaining $\mathrm{AB}$; Sp on T2-3 shifted anteriorly and pointing toward head (Fig. 10).

Three pairs of scoli from $\mathrm{AB} 1$ to $\mathrm{AB} 8$, one dorsal (So) pair, one supra-spiracular ( $\mathrm{Sp}$ ) pair, and one subspiracular (Sl) pair, following the Heliconiini pattern (e.g., KAMINSKI et al., 2008; SILVA et al., 2008; BARÃo \& MoreIra, 2010). Abdominal scoli shorter than height of abdominal segments, as in $H$. erato phyllis (KAMINSKI et al., 2002). On AB9 only So is present. One pair of anal scoli (Sn) on AB10.
Several minute, black pinnacles and verrucae scattered over integument; on each abdominal segment, posterior to scoli, pinnacles organized in transverse band (Fig. 35). Primary setae SV1 replaced by verruca on AB1, $\mathrm{AB} 2, \mathrm{AB} 7$, and $\mathrm{AB} 8$.

Head integument with striated, semi-spherical sculpturing (Fig. 26). Ventral body surface and base of prolegs provided with conical, smooth and apically acute microtrichia (Fig. 27); laterally and dorsally, larval body bearing smooth, semi-spherical microtrichia (Fig. 28). Conical sensilla on anal shield (Fig. 29). Elliptic spiracles (Fig. 30). Triordinal and uniserial crochets (Fig. 31) on base of prolegs.
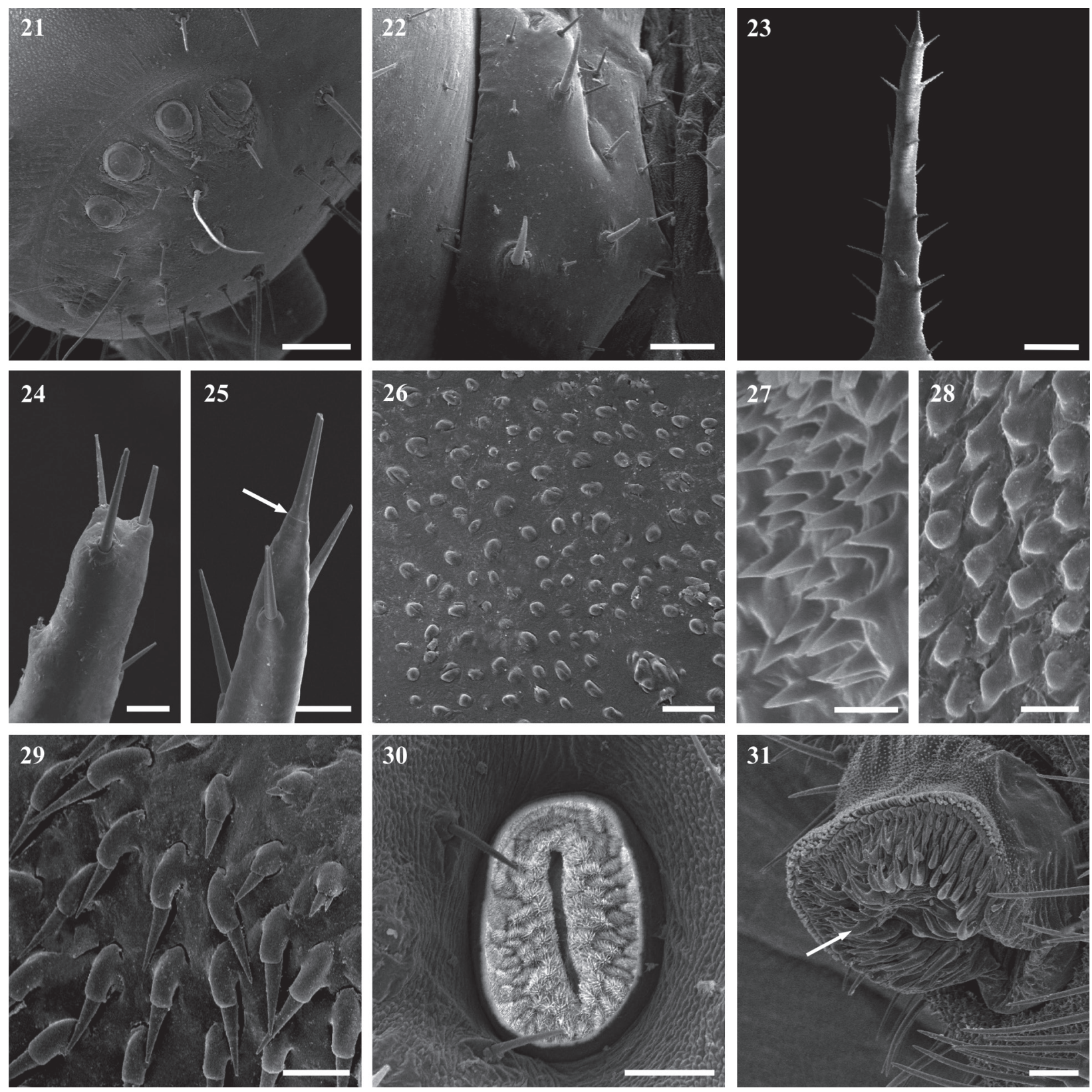

Figs 21-31. Scanning electron micrographs of the fifth instar larva of Heliconius sara apseudes (Hübner, [1813]). 21, stemmatal region, lateral view; 22, prothoracic plate, dorsolateral view; 23 , dorsal scolus; 24 , apex of cephalic scolus; 25 , apex of dorsal scolus with one seta (arrow); 26, ornament of head integument; 27, microtrichia of proleg; 28, microtrichia of lateral region of body; 29, epiproct sensilla; 30, spiracle of first abdominal segment; 31 , base of proleg with exposed crochets (arrow). Bars $=200,200,500,100,100,20,10,10,50,100$ and $100 \mathrm{~mm}$, respectively. 

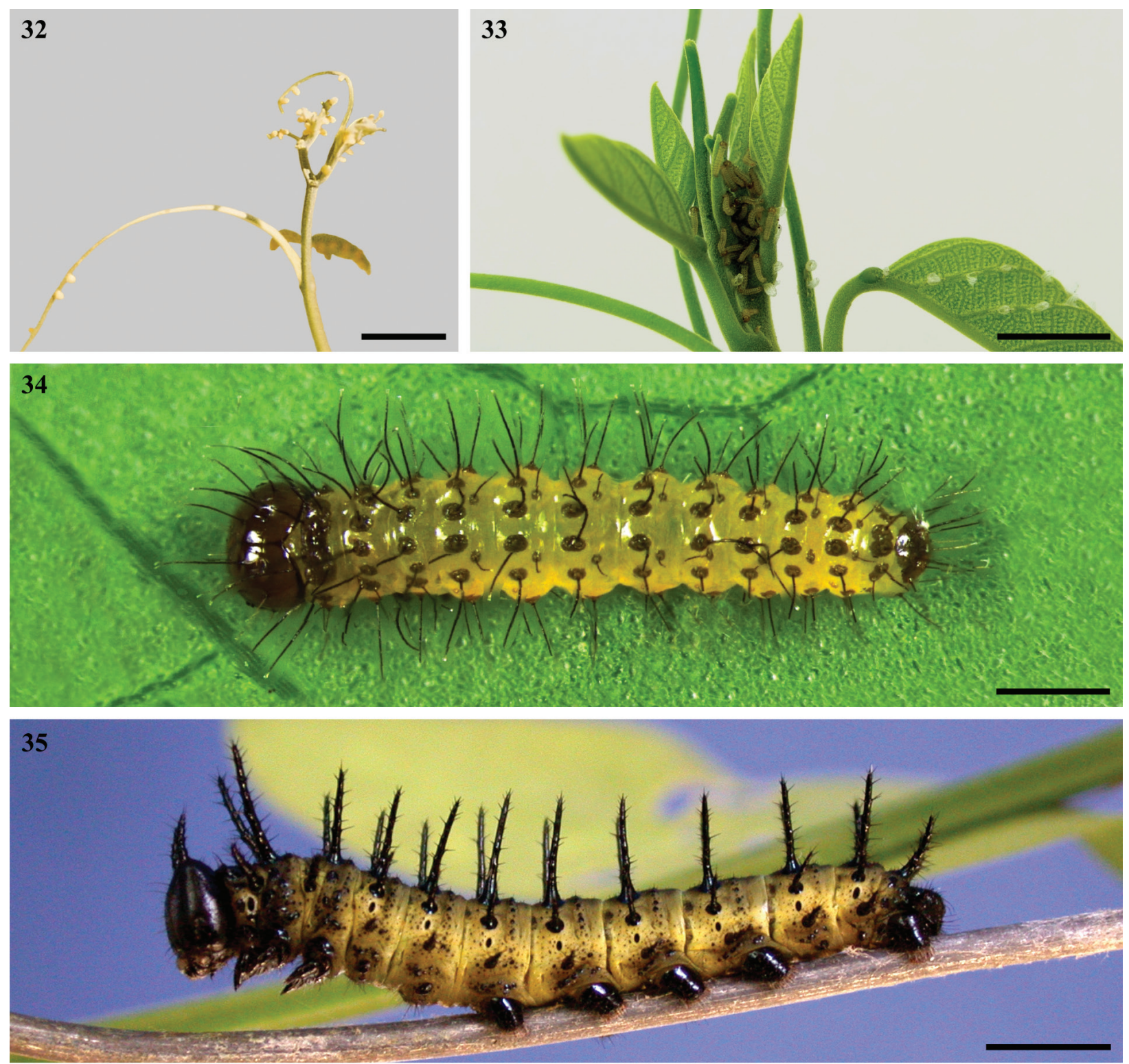

\section{6}

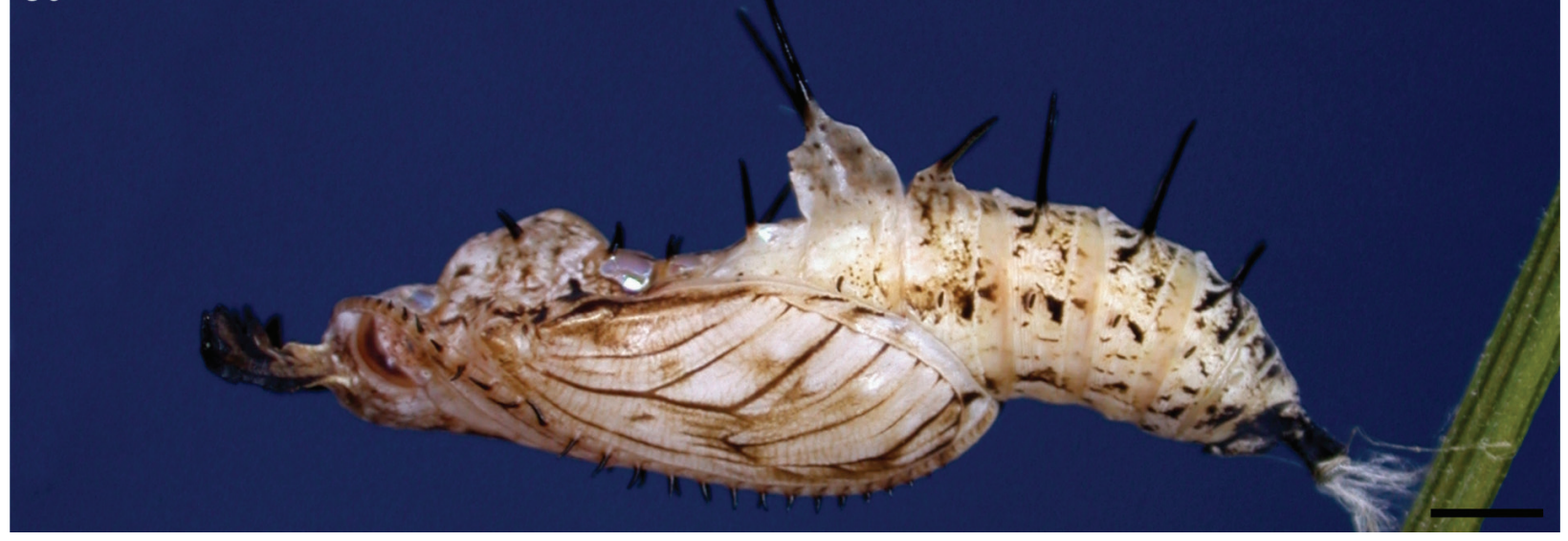

Figs 32-36. Coloration pattern of Heliconius sara apseudes (Hübner, [1813]) egg, larval and pupal stages. 32, eggs laid on Passiflora truncata; 33, hatchlings on Passiflora haematostigma; 34, first-instar larva, dorsal view; 35, fifth-instar larva, lateral view; 36, pupa, lateral view. Bars = 20, 10, $0.5,5,2.5 \mathrm{~mm}$, respectively. 

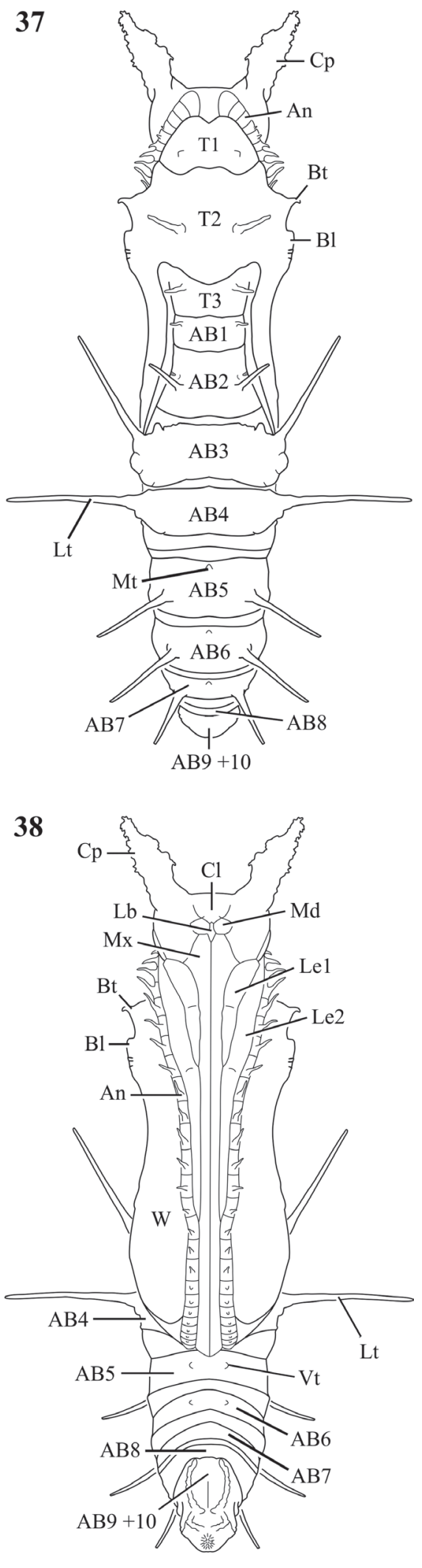

Figs 37, 38. Pupa of Heliconius sara apseudes (Hübner, [1813]). 37, dorsal view; 38 , ventral view (AB, abdominal segment; An, antenna; $\mathrm{Bl}$, longitudinal crest; $\mathrm{Bt}$, basilar tubercle; $\mathrm{Cl}$, clypeus; $\mathrm{Cp}$, cephalic projection; Lb, labium; Le1, prothoracic leg; Le2, mesothoracic leg; Lt, laterodorsal tubercle; Md, mandible; Mt, mediodorsal tubercle; Mx, maxilla; T, thoracic segment; Vt, ventral tubercle; $\mathrm{W}$, wing). Bars $=2.5 \mathrm{~mm}$.
As in the first instar, the gross morphology and chaetotaxy of the subsequent instars of $H$. sara apseudes fit the general pattern described for Heliconiini (BEEBE et al., 1960; ANTUNES et al., 2002; KAMINSKI et al., 2002, 2008; TAVARES et al., 2002; PAIM et al., 2004; SiLva et al., 2006, 2008; BarÃo \& Moreira, 2010; VARgas et al., 2014). From the second to fifth instars, the coloration of $H$. sara apseudes differs from those of $H$. besckei, H. erato phyllis and $H$. ethilla narcaea, which have the head in varying shades of yellow and the body white with black spots. The multiple setae on apex of Sc and So on T2 projected anteriorly and larger than any other scoli are also unique features of $H$. sara apseudes larvae (BEEBE et al., 1960; TAVARes et al., 2002; KaminsKi et al., 2002, 2008; PAim et al., 2004; SiLVA et al., 2006, 2008; BARÃo \& MoreIra, 2010; VARGAS et al., 2014).

Instar identification. Besides the striking differences in chaetotaxy and coloration between the first and remaining instars, there are insufficient morphological or coloration changes to precisely identify instars of $\mathrm{H}$. sara apseudes. However, they can be accurately distinguished by the size of their head capsule, because head widths of successive instars do not overlap (Tab. I). The following exponential growth equation was adjusted for the five instars: $\mathrm{y}=0.0289 \mathrm{e}^{\wedge} 0.533 \mathrm{x} ; \mathrm{n}=59 ; \mathrm{r}=0.98 ; \mathrm{p}=0.0001$. The mean growth ratio among instars was 1.67 , similar to ratios previously reported for other Neotropical heliconiines (ANTUNES et al., 2002; KAMINSKI et al., 2002, 2008; TAVARES et al., 2002; PAIM et al., 2004; SiLVA et al., 2006, 2008; BARÃo \& Moreira, 2010; VARGAS et al., 2014).

Pupa (Figs 36-53). Yellowish with scattered black markings (Fig. 36); dorsal pairs of golden spots on T1, T3, AB1, and AB2. BEeBE et al. (1960) noted the absence of dorsal golden spots on $\mathrm{T} 2$ for populations of $H$. sara in Trinidad.

Head with pair of long, compressed cephalic projections (Figs 37-40); edges of cephalic projections irregular. Ventrally, mandibles (Md; Figs 38, 41) surrounding labrum $(\mathrm{Lb})$; clypeus $(\mathrm{Cl}$; Fig. 38,41$)$ anterior to $\mathrm{Lb}$; maxillae $(\mathrm{Mx})$ posterior to $\mathrm{Lb}$, extending to distal portion of antennae (Fig. 38); eyes (Fig. 42) with sculptured region near antennae, bearing few, short, apically clavate setae (Fig. 43), and another smooth region near frons. Antennae (An) arising dorsally on head (Fig. 37), projected ventrally between maxillae and legs, reaching apex of maxillae; each antennomere with an elongated, spike-like tubercle (Fig. 44).

Pro- (Le1) and mesothoracic (Le2) legs (Fig. 38) visible in ventral view; metathoracic leg concealed by antennae; Le1 and Le2 each with tibial tubercles (Fig. 44), similar to H. erato phyllis (KAMINSKI et al., 2002). Each forewing with sharp basilar tubercle (Bt) and longitudinal crest (Bl) basally (Fig. 45); three slightly pronounced submarginal tubercles (St). Mesothorax (T2) with median meso-dorsal crest (Fig. 45). Medio-dorsal (Mt) tubercle on anterior margin of each AB5-7 (Fig. 46). Spike-like laterodorsal (Lt) tubercles from T2 to AB7 (Figs 36-38, 47); 
Tab. I. Mean and standard error (SE), interval of variation (IV), and growth rates (GR) of the head-capsule width in larval instars of Heliconius sara apseudes (Hübner, [1813]), reared on Passiflora haematostigma Masters.

\begin{tabular}{ccccc}
\hline & & & Head-capsule width (mm) \\
\cline { 3 - 5 } Instar & $\mathrm{N}$ & Mean \pm SE & IV & GR \\
\hline I & 13 & $0.456 \pm 0.007$ & $0.388-0.493$ & \\
II & 16 & $0.860 \pm 0.007$ & $0.810-0.907$ & 1.884 \\
III & 16 & $1.557 \pm 0.021$ & $1.367-1.651$ & 1.812 \\
IV & 9 & $2.460 \pm 0.035$ & $2.210-2.543$ & 1.579 \\
V & 5 & $3.496 \pm 0.047$ & $3.349-3.594$ & 1.421 \\
\hline
\end{tabular}
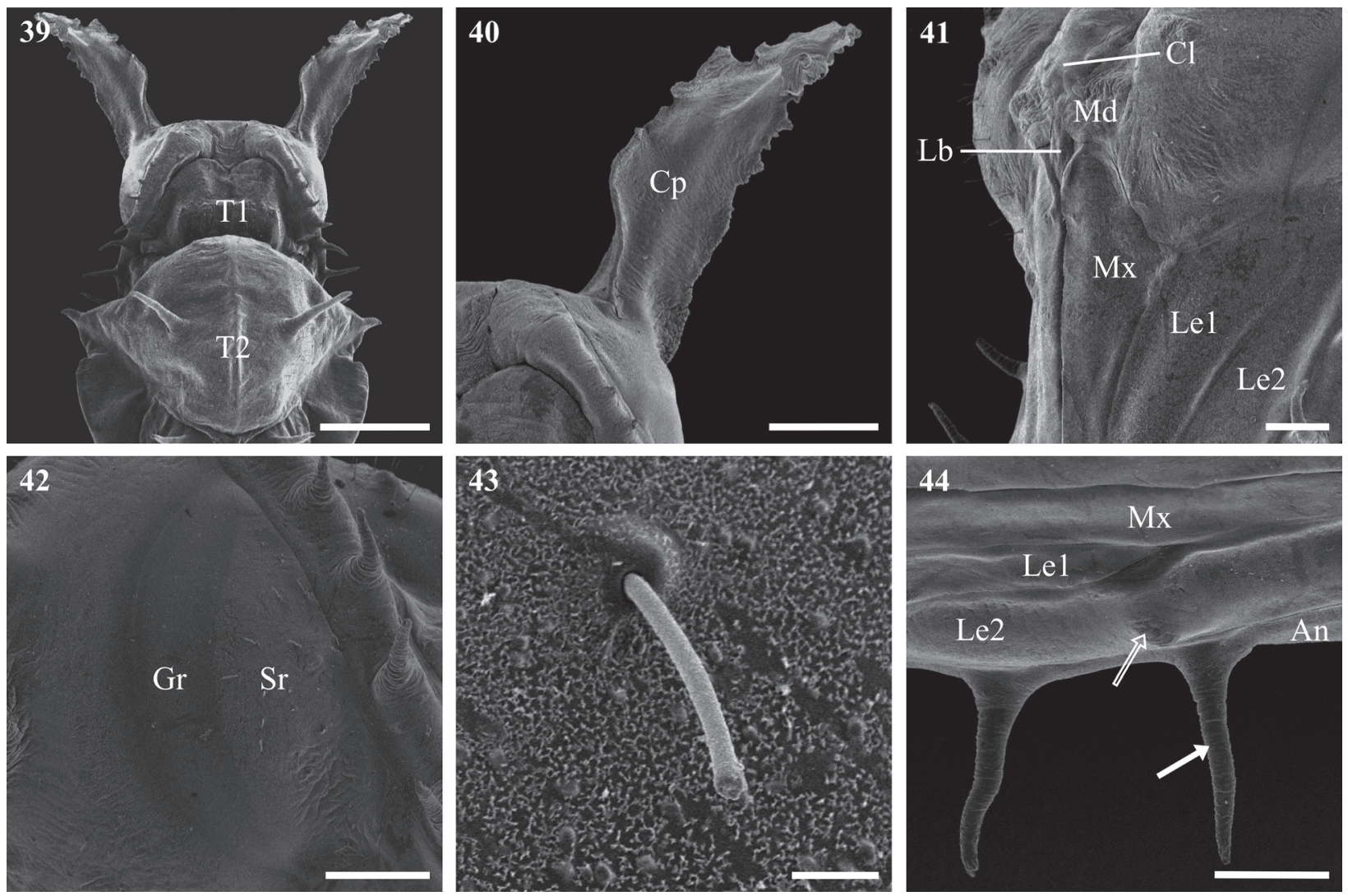

Figs 39-44. Scanning electron micrographs of the pupa of Heliconius sara apseudes (Hübner, [1813]). 39, head and thorax, dorsal view; 40, cephalic projection, dorsal view; 41, mouthparts, ventrolateral view; 42, eye, lateral view; 43, seta from sculptured region of eye; 44, tubercles on antenna (solid white arrow) and mesothoracic leg (hollow white arrow) (An, antenna; Cl, clypeus; Cp, cephalic projection; Gr, glazed stripe of eye; Lb, labium; Le1, prothoracic leg; Le2, mesothoracic leg; Md, mandible; Mx, proximal portion of maxilla; Sr, sculptured region of eye; T, thoracic segment). Bars $=2000,1000,500,500,25$ and $500 \mathrm{~mm}$, respectively.

base of each Lt on AB3 and AB4 expanded longitudinally, forming flanges (Fig. 47); flanges not fused with each other; spike-like projections of Lt on AB3 and AB4 directed anteriorly and laterally, respectively. Supra-spiracular (Se) tubercles present from AB2 to AB4 (Fig. 48). Pairs of sub-median, ventral (Vt) tubercles present on AB6 and AB7 (Fig. 38).

Mesothoracic spiracle (Fig. 49) cleft-shaped; abdominal spiracles elliptic (Fig. 50), visible from AB2 to AB7. Integument bearing scattered semi-spherical protuberances and covered with waxy layer (Fig. 51). Cremaster subquadrate (Fig. 52), with hooks; each hook with recurved apex directed toward its base (Fig. 53).

The gross morphology of the pupa of $H$. sara apseudes is similar to other Heliconiini, following the pattern proposed by Mosher (1916) for Nymphalidae. The presence of spike-like tubercles on the antennae, thorax and abdomen, well-developed latero-dorsal flanges at least on $\mathrm{AB} 3$, and three to five pairs of dorsal golden spots fits the morphological pattern of "Group C" proposed by BeEBe et al. (1960). Other species of Heliconius (e.g. $H$. erato, $H$. wallacei and $H$. melpomene) also fit this pattern (BEEBE et al., 1960).

The cephalic projections of $H$. sara apseudes are similar to those of $H$. erato phyllis and Dryadula phaetusa (Linnaeus, 1758) (KAminsKi et al., 2002; SiLVA et al., 2008) and differ from the short and palmate cephalic projections of Dryas iulia alcionea (Cramer, 1779), Agraulis vanillae maculosa (Stichel, [1908]) and Philaethria wernickei (Röber, 1906) (PAIM et al., 2004; SILVA et al., 2006; BARÃo $\&$ MoreIRA, 2010). Thoracic and abdominal tubercles of $H$. sara apseudes are similar to those of $H$. erato phyllis 

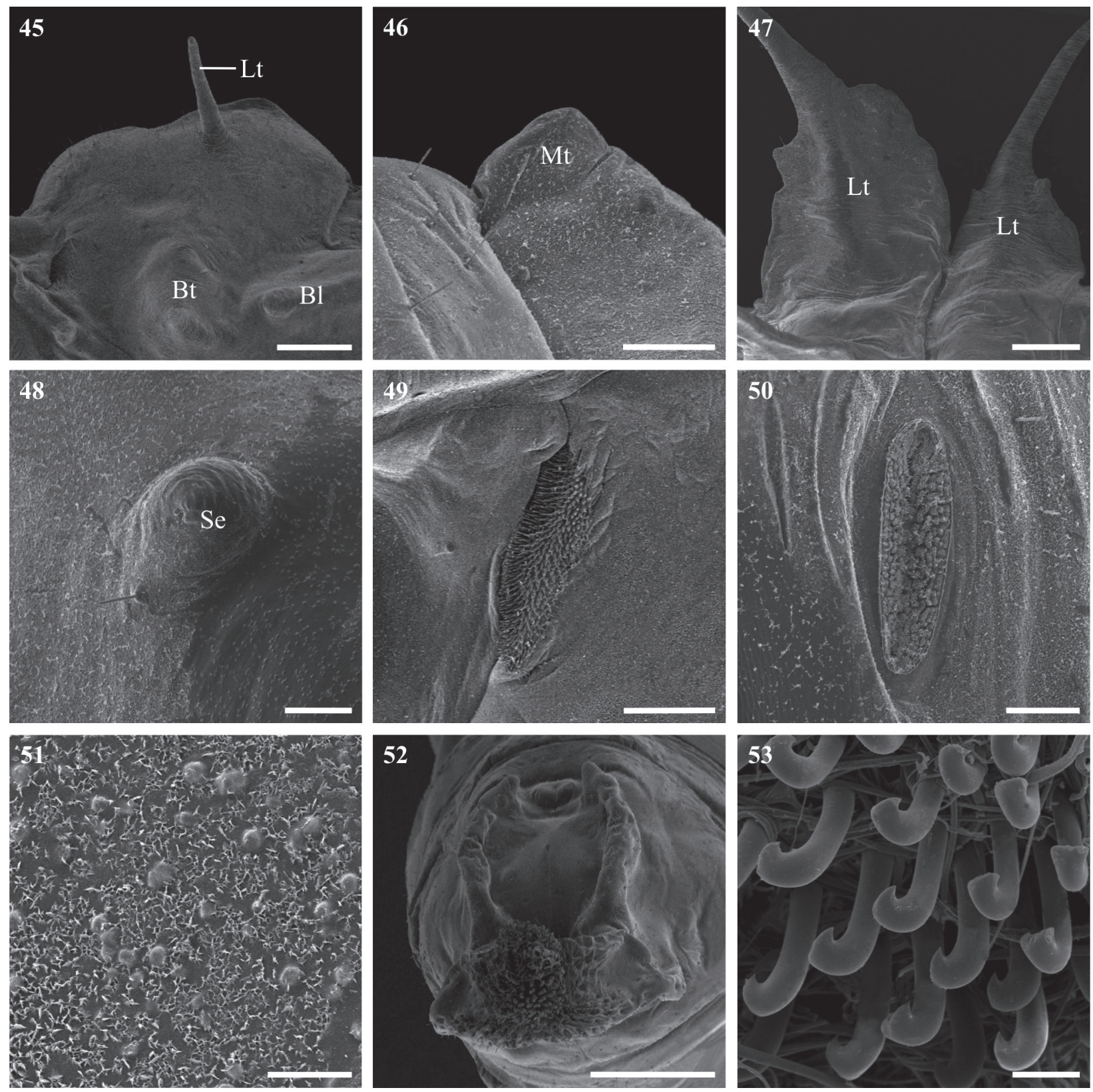

Figs 45-53. Scanning electron micrographs of the pupa of Heliconius sara apseudes (Hübner, [1813]). 45, mesothoracic segment, lateral view; 46, mediodorsal tubercle, lateral view; 47, third and fourth laterodorsal tubercles, internal dorsal view; 48, supraspiracular tubercle, lateral view; 49, mesothoracic spiracle; 50, spiracle of eighth abdominal segment; 51, detail of tegumentary sculpture, 52, cremaster, posteroventral view; 53, cremaster hooks (Bl, longitudinal crest; Bt, basilar tubercle; Lt, laterodorsal tubercle; Mt, mediodorsal tubercle; Se, supraspiracular tubercle). Bars $=1000,200,1000,100,250,100,20,1000$ and $50 \mathrm{~mm}$, respectively.

(KAMINSKI et al., 2002); the Lt differs from H. erato phyllis in not having the flanges of thoracic Lt tubercles fused (KAMINSKI et al., 2002).

Acknowledgments. We are indebted to Eduardo C. dos Santos and Diego R. Dolibaina (UFPR) for their support in collecting immature specimens of $H$. sara apseudes in Paraná, and to staff members of the Centro de Microscopia Eletrônica of UFRGS for the use of facilities and for their assistance in scanning electron microscopy analyses. Thanks are also due Janet W. Reid for editing the text. This study was funded by a grant from the Conselho Nacional de Desenvolvimento Científico e Tecnológico - CNPq (\#309676/2011-8) to GRPM; KRB is supported by a CNPq Postdoctoral Fellowship (Process \#150712/2015-4) and DSS by a CAPES Doctoral Fellowship.

\section{REFERENCES}

Antunes, F. F.; Menezes, A. O., Jr.; Tavares, M. \& Moreira, G. R. P. 2002. Morfologia externa dos estágios imaturos de heliconíneos neotropicais: I. Eueides isabella dianasa (Hübner, 1806). Revista Brasileira de Entomologia 46:601-610.

BALLMER, G. R. \& WRIGHT, D. M. 2008. Life history and larval chaetotaxy of Ahmetia achaja (Lepidoptera, Lycaenidae, Lycaeninae, Theclini, Cheritrina). Zootaxa 1845:47-59.

Barão, K. R. \& Moreira, G. R. P. 2010. External morphology of the immature stages of Neotropical heliconians: VIII. Philaethria wernickei (Röber) (Lepidoptera, Nymphalidae, Heliconiinae). Revista Brasileira de Entomologia 54:406-418.

Beccaloni, G. W.; Viloria, A. L.; Hall, S. K. \& Robinson, G. S. 2008. Catalogue of the hostplants of the neotropical butterflies/ 
Catálogo de las plantas huésped de las mariposas neotropicales. Vol. 8. Zaragoza, Sociedad Entomológica Aragonesa (S.E.A.). 536p.

Beebe, W.; Crane, J. \& Fleming, H. 1960. A comparison of eggs, larvae and pupae in fourteen species of heliconiine butterflies from Trinidad, W. I. Zoologica 45:111-154.

Beltrán, M.; Jiggins, C. D.; Brower, A. V. Z.; Bermingham, E. \& Mallet, J. 2007. Do pollen feeding, pupal-mating and larval gregariousness have a single origin in Heliconius butterflies? Inferences from multilocus DNA sequence data. Biological Journal of the Linnean Society 92:221-239.

Brown, K. S., JR. 1981. The biology of Heliconius and related genera. Annual Review of Entomology 26:427-456.

CArdoso, M. Z. 2005. New locaties for Heliconius besckei Ménétriés and Heliconius sara (Fabricius) (Lepidoptera: Nymphalidae) in Bahia, Brazil. Neotropical Entomology 34:1007-1008.

Casagrande, M. M. 2002. Naropini Stichel, taxonomia e imaturos (Lepidoptera, Nymphalidae, Brassolinae). Revista Brasileira de Zoologia 19:467-569.

Dell'Erba, R.; Kaminski, L. A. \& Moreira, G. R. P. 2005. O estágio de ovo dos Heliconiini (Lepidoptera, Nymphalidae) do Rio Grande do Sul, Brasil. Iheringia, Série Zoologia 95:29-46.

Downey, J. C. \& Allyn, A. C., JR. 1981. Chorionic sculpturing in eggs of Lycaenidae. Part I. Bulletin of the Allyn Museum 61:1-29.

Duarte, M.; Robbins, R. K. \& Mielke, O. H. H. 2005. Immature stages of Calycopis caulonia (Hewitson, 1877) (Lepidoptera, Lycaenidae, Theclinae, Eumaeini), with notes on rearing detritivorous hairstreaks on artificial diet. Zootaxa 1063:1-31.

Emsley, M. G. 1963. A morphological study of imagine Heliconiinae (Lepidoptera: Nymphalidae) with a consideration of the evolutionary relationships within the group. Zoologica 48:85-130.

FLEMING, H. 1960. The first instar larvae of the Heliconiinae (Butterflies) of Trinidad, W. I. Zoologica 45:91-110.

Harvey, D. J. 1991. Higher classification of the Nymphalidae. In: NiJHOUT, H. F. ed. The development and evolution of butterfly wing patterns. Washington, D.C., Smithsonian Institution Press, p. 255-273.

Hinton, H. E. 1946. On the homology and nomenclature of the setae of lepidopterous larvae, with some notes on the phylogeny of the Lepidoptera. Transactions of the Royal Entomological Society of London 97:1-37.

HolzINGer, H. \& HolzINGER, R. 1994. Heliconius and related genera: Lepidoptera Nymphalidae. The genera Eueides, Neruda and Heliconius. Vennete, Sciences Nat. 328p.

Iserhard, C. A.; Silva, A. K.; Quadros, M. T.; Castro, D. S. \& RomANOwSKI, H. P. 2010. Lepidoptera, Nymphalidae, Heliconiinae, Heliconius sara apseudes (Hübner, 1813): Distribution extension. Check List 6:316-318.

Kaminski, L. A.; Dell'Erba, R. \& Moreira, G. R. P. 2008. Morfologia externa dos estágios imaturos de heliconíneos neotropicais. VI. Dione moneta moneta Hübner (Lepidoptera, Nymphalidae, Heliconiinae). Revista Brasileira de Entomologia 52: 13-23.

Kaminski, L. A.; Tavares, M.; Ferro, V. G. \& Moreira, G. R. P. 2002. Morfologia externa dos estágios imaturos dos heliconíneos neotropicais. III. Heliconius erato phyllis (Fabricius) (Lepidoptera, Nymphalidae, Heliconiinae). Revista Brasileira de Zoologia 19:977-993.

Kitching, I. J. 1984. The use of larval chaetotaxy in butterfly systematics, with special reference to the Danaini (Lepidoptera: Nymphalidae). Systematic Entomology 9:49-61.

Kozak, K. M.; Wahlberg, N.; Neild, A. F. E.; Dasmahapatra, K. K.; Mallet, J. \& JigGins, C. D. 2015. Multilocus species trees show the recent adaptive radiation of the mimetic Heliconius butterflies. Systematic Biology 64:505-524
Miller, J. S. 1991. Cladistics and classification of the Notodontidae (Lepidoptera: Noctuoidea) based on larval and adult morphology. Bulletin of the American Museum of Natural History 204:1-230.

Mosher, E. 1916. A classification of the Lepidoptera based on characters of the pupa. Bulletin of the Illinois State Laboratory of Natural History 12:1-165.

MüLLER, W. 1886. Südamerikanische Nymphalidenraupen. Versuch eines naturlichen Systems der Nymphaliden. Zoologische Jahrbücher 1:417-678.

Murray, D. 2001. Immature stages and biology of Taygetis Hübner (Lepidoptera: Nymphalidae). Proceedings of the Entomological Society of Washington 103:932-945.

NAKANISHI, A. 1988. Study on the first instar larvae of the subfamily Nymphalinae (Lepidoptera, Nymphalidae). Special Bulletin of the Lepidopterological Society of Japan 6:83-99.

Paim, A. C.; Kaminski, L. A \& Moreira, G. R. P. 2004. Morfologia externa dos estágios imaturos de heliconíneos neotropicais. IV. Dryas iulia alcionea (Lepidoptera, Nymphalidae, Heliconiinae). Iheringia, Série Zoologia 94:25-35.

Paluch, M.; Casagrande, M. M. \& Mielke, O. H. H. 1999. Estágios imaturos de Actinote surima (Schaus) (Lepidoptera, Nymphalidae, Acraeinae). Revista Brasileira de Zoologia 16:129-140.

.2001. Estágios imaturos de Actinote carycina Jordan (Lepidoptera, Nymphalidae, Acraeinae). Revista Brasileira de Zoologia 18:883896.

Penz, C. M. 1999. Higher level phylogeny for passion-vine butterflies (Nymphalidae, Heliconiinae) based on early stage and adult morphology. Zoological Journal of the Linnean Society 127:277344.

Peterson, A. 1962. Larvae of insects. An introduction to Neartic species. Part I Lepidoptera and plant infesting Hymenoptera. Ann Arbor, Edwards Brothers Inc. 315p.

Rosser, N.; Phillimore, A. B.; Huertas, B.; Willmott, K. R. \& Mallet, J. 2012. Testing historical explanations for gradients in species richness in heliconiine species of tropical America. Biological Journal of the Linnean Society 105:479-497.

SAKAMAKI, Y. \& HaYAKaWA, T. 2004. Specific differences in larval and pupal characters of Japanese species of Adoxophyes (Lepidoptera, Tortricidae). Applied Entomology and Zoology 39:443-453.

Silva, D. S.; Dell'Erba, R.; Kaminski, L. A. \& Moreira, G. R. P. 2006. Morfologia externa dos estágios imaturos de heliconíneos neotropicais: V. Agraulis vanillae maculosa (Lepidoptera, Nymphalidae, Heliconiinae). Iheringia, Série Zoologia 96:219-228.

Silva, D. S.; Kaminski, L. A.; Dell'Erba, R. \& Moreira, G. R. P. 2008. Morfologia externa dos estágios imaturos de heliconíneos neotropicais: VII. Dryadula phaetusa (Linnaeus) (Lepidoptera, Nymphalidae, Heliconiinae). Revista Brasileira de Entomologia 52:500-509.

Snedecor, G. W. \& Cochran, W. G. 1980. Statistical methods. Ames, Iowa State University. 507p.

Stehr, F. W. 1987. Order Lepidoptera. In: Stehr, F. W. ed. Immature insects. Vol. 1. Dubuque, Kendall/ Hunt Publishing Company, p. 288-305.

Tavares, M.; Kaminski, L. A. \& Moreira, G. R. P. 2002. Morfologia externa dos estágios imaturos dos heliconíneos neotropicais. II. Dione juno juno (Cramer) (Lepidoptera, Nymphalidae, Heliconiinae). Revista Brasileira de Zoologia 19:961-976.

Vargas, H. A.; Barão, K. R.; Massardo, D. \& Moreira, G. R. P. 2014. External morphology of the immature stages of Neotropical heliconians: IX. Dione glycera (C. Felder \& R. Felder) (Lepidoptera, Nymphalidae, Heliconiinae). Revista Brasileira de Entomologia 58:129-141. 